\title{
Kadın Cinsel İstismarcılar
}

\section{Female Perpetrators of Sexual Abuse}

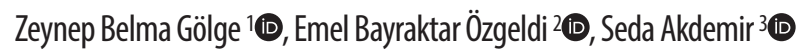

\begin{abstract}
$\ddot{0} z$
Kadınların cinsel istismarcı olabilme potansiyeli yakın zamana kadar kabul edilmemiştir. Özellikle kadınların cinsel saldırılarda "saldırgan"dan ziyade "mağdur" olarak tanımlanması, ayrıca çocuklar için temel bakıı figürü olarak değerlendirilmeleri onların istismarcı olabilme potansiyellerinin göz ardı edilmesinin temel nedenlerinden biri olabilmektedir. Elde edilen son bulgular kadınların tanıdıkları ve özellikle bakım verdikleri çocukları istismar edebileceklerini göstermektedir. Kadın cinsel istismarcılar konusunda yakın dönemli çalışmaların da artmasıyla kadın istismarcıların yaygınlığı ve özellikleri hakkında bilgiler edinilmeye başlanmış olsa da bu grup hakkında erkek cinsel istismarcılar kadar detaylı bilgileri henüz elde edilememiştir. Kadın cinsel istismarcıların yaygınlı̆ı konusunda da henüz net bir oran bulunmamakla birlikte yakın dönemli çalışmalarda düşünüldüğünden çok daha fazla olduğu ifade edilmektedir. Yapılan çalışmalarda kadın cinsel istismarı mağdurlarında sıkıkla kadınlarla sorunlu ilişkiler, depresyon, madde kullanımı, intihar girişimleri, kaygı bozuklukları, cinsel bozukluklar, benlik karmaşası, ihanete uğrama hissi rapor edilmektedir. Kadın cinsel istismarcıların tedavisinde erkek istismarcılar için uygulanan programlar sıklıkla kullanılmakta ancak bu programlar kadın istismarcıların ihtiyaçlarına yanıt vermemektedir. Ülkemizde kadın cinsel istismarcılara yönelik düzenli verilerin olmadığı görülmekle birlikte, konu hakkında yürütülecek çalışmalara ihtiyaç duyulmaktadır.
\end{abstract}

Anahtar sözcükler: Kadın istismarcılar, cinsel istismar, kadın pedofiller

\section{Abstract}

Women's potential for sexual abuse was not recognized, until recently. Defining women as "victims" rather than "aggressors" in sexual assaults and also considering women as "primary caregivers" for children may be one of the main reasons for ignoring their potential to be sexually abusive. Recent findings showed that women sexually abuse children they closely know, and care for. Although, the information about prevalence and characteristics of female-perpetrated sexual abuse has started to be obtained with the increase in research on female sexual abusers, detailed information as much as male sexual abusers are still necessary. Although the prevalence of female-perpetrated sexual abuse is not precise, recent research suggest that is much higher than thought. Studies reported problematic relationships with women, depression, substance abuse, suicide attempts, anxiety problems, sexual problems, identity confusion, feelings of betrayal in the victims of female-perpetrated sexual abuse. Treatment programs for male sexual abusers are frequently used in the treatment of female abusers, but these programs do not respond to the needs of female sexual abusers. There is an absence of regular data on female sexual abusers in Turkey, so studies on female sexual abusers and the victims are required.

Keywords: Female abusers, sexual abuse, female pedophiles

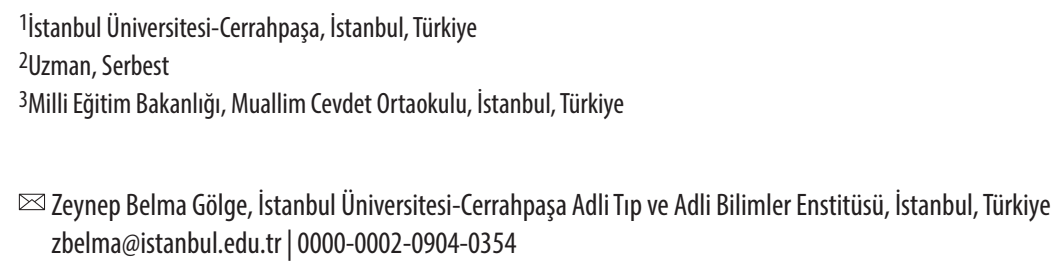

Geliş tarihi/Received: 05.11.2020| Kabul tarihi/Accepted: 24.12.2020 | Çevrimiçi yayın/Published online: 03.06.2021 
CINNSEL suçlara ilişkin literatür erkek faillere odaklanmış olup bu da cinsel açıdan istismarcı davranışlarda bulunan kadınlara ilginin çok kısıtlı kalmasına neden olmuştur (Gannon ve Cortoni 2010). Tarihsel süreçte kadın, çocuk cinsel istismarının mağduru olarak tanımlandığından cinsel istismar faili olarak kadınlar araştırmalarda çok az yer almıştır (Grayston ve De Luca 1999).

Kadınların cinsel anlamda istismarcı olabilme ihtimalinin varlığına dahi yıllarca karşı çıkılmış ve bir kadının herhangi bir çocuk veya erkek için cinsel açıdan tehlikeli olması tuhaf bulunmuştur (Denov 2004). Söz konusu kadın istismarcıların gerçekte kim olduğuna dair bilgi halen çok yetersiz ve son derece değişken olup araştırmacılar arasında farklllık gösterdiğinden bu kadınların özelliklerini değerlendirmek de güçleşmektedir. Mevcut veriler çelişkiler içermekte, sıklıkla az sayıda olguya (bazen ondan az) dayalı sınıflandırmalar üzerinden tartı̧̧lmakta, hatta kimi zaman gerçeklerden ziyade kişisel veya siyasi fikirlerle değerlendirilmektedir (Grayston ve De Luca 1999, Johansson-Love ve Fremouw 2006).

Kadınlar uzun yıllardır fiziksel çocuk istismarı olaylarında suçlu olarak görülmüş olsa da klinisyenlerin ve araştırmacıların kadınların çocukları cinsel olarak istismar edişini ciddi olarak ele almaya başlayışı oldukça yenidir. Uluslararası alanyazında, kadın cinsel istismarcıların özelliklerine, mağdur üzerindeki etkilerine ve tedavi programı veya protokolüne yönelik çalı̧malar yer almaktadır. Oysa ülkemizde bu konu ile ilgili herhangi bir çalışmaya rastlanmamıştır. Bu yazı ile özellikle son yıllarda çalışılmaya başlanan kadın cinsel istismarcılar ile ilgili alanyazındaki bu eksikliği gidermek amaçlanmıştır.

\section{Kadın ve cinsel istismar algısı}

Kadının toplumsal rolü ile ilgili gelişmelere rağmen, kadınlara dair algı halen çeşitli kalıp yargılar içermektedir ve suç işleyen kadınlar da bu durumun istisnası değildir (Herzog ve Oreg 2008). Cinsel istismarcı kadınlar kadınlığa ilişkin sosyal algıları temelden sarsmaktadır çünkü toplumda kadınları fail değil, çocukların bakıcısı ve mağdur olarak tanımlama eğilimi vardır (Mendel 1995). Kadının toplumda algılanan rolü bakım sağlayan, besleyip büyüten kişi olduğundan, bu kimliğin dışına çıkan kadınlara şüphe, tiksinme veya görmezden gelme ile yaklaşılmaktadır (Yoder 2003). Kadınlar, çocuklara karşı cinsel olarak zararsız olarak görülmektedir. "Penisi olmadan ne gibi zararı olabilir?" yönünde ortak bir düşünce vardır (Boroughs 2004). Bir kadının penetrasyon için bir penisi olmadan bir çocuğu cinsel olarak nasıl istismar edebileceğini anlamak zordur. Bazen de kadınların cinsel istismarcı olabileceği kabul edilmekte ancak istismara uğrayan çocuğun bu durumdan çok fazla etkilenmeyeceği (Akdemir ve Gölge 2019), erkek istismarcıların kadın istismarcılardan daha zarar verici olduğu ve kadın istismarcılara göre daha fazla odaklanılması gerektiği düşünülmektedir (Elliot 1994). Ancak 50 kadın istismarc1 mahkum ile yapılan bir çalışmada kadınların yarısı, mağdurlarına acı vermekten keyif aldıklarını belirtmiştir (Elliot 1994, Boroughs 2004).

Çocuklarına cinsel istismarda bulunmuş anneleri tedavi eden Banning'e (1989) göre, anneler çocukların günlük bakımı ve temizliğinden sorumlu olduğundan çocuklarla kurdukları doğal temas aralı̆ı hayli genişken, toplum çocuklarının bakımını üstlenen 
erkeklere aynı hoşgörüyü sunmamaktadır. Tipik olarak bir toplumda annenin oğluyla aynı yatakta uyuması doğal karşılanırken bir baba kızıyla benzer şekilde uyuduğunda olumsuz anlamlar yüklenmektedir (Banning 1989). Bunun temel nedeni, kadınların çocuk büyütmede oynadığı bakıcı rolüdür. Denov’a (2004b) göre kadınlar sıklıkla anne ve bakıcı rolünü üstlendiğinden çocukların büyütülmesiyle ilişkili olarak algılanmakta; bu da kadınların cinsel suç işleyebileceğini kabul etmeyi reddeden toplumsal bir "inkar kültürü"ne neden olmaktadır. Yanı sıra, geleneksel cinsiyet tanımlamalarında erkekler tüm cinsel temasları kontrol eden taraf olarak resmedilirken kadınlar ise pasif ve itaatkar taraf olarak belirtilmektedir (Becker ve ark. 2001). Dolayısıyla, kadınların cinsel saldırı ve tecavüz suçlarını işleyebileceğini kabul etme konusundaki tereddüt geleneksel toplumsal cinsiyet rolleri ve kadın ile erkek cinsiyetine atfedilen cinsel davranışlar üzerinden devam etmektedir (Cain ve Anderson 2016). Bunun uzantısı olarak kadınlar tarafindan uygulanan cinsel istismar, erkeklerce gerçekleştirilen cinsel istismara kıyasla daha az zararlı ve daha az ciddi görülmektedir (Broussard ve ark. 1991, Finkelhor ve ark. 1988). Bazılarına göre, bir erkek çocuğun yetişkin bir kadın tarafından istismarı her erkek çocuğunun fantezisidir ve/veya yetişkin bir adamın bir kız çocuğunu istismar edişinden daha az travmatiktir (Hetherton ve Beardsall 1998).

\section{Yayginlık}

Literatürde genel popülasyon düşünüldüğünde "çocuklar ile ileri yaşlardaki kadınlar arasındaki cinsel ilişkinin çocuk-yetişkin ilişkilerinin çok küçük bir kısmını oluşturduğu” yönünde bir uzlaşma belirtilmiş (Finkelhor ve Russell 1984) olsa da çocukların ve ergenlerin maruz kaldığı cinsel istismar olaylarının önemli bir kısmında kadınların da yer aldığ bilinmektedir (Kaufman ve ark.1995). Ford (2006) kadın cinsel istismarının nadir mi yoksa az $\mathrm{m}$ bildirildiği konusunun önemini vurgular. Mağdurlarla yapılan öz bildirim çalışmalarında kadın istismarcı oranlarının resmi olarak bildirilen oranlardan daha yüksek olduğunu belirtir. Elliott (1994) geçmişte erkeklerin de istismarı nadir olarak gerçekleştirdiğinin düşünüldüğünü ve toplum içindeki yüzdelerinin düşük olduğunu, ancak bildirilen olgular arttıkça bu oranların da arttığını belirtmiştir. Kadınlar tarafından gerçekleştirilen cinsel istismar çoğunlukla kadının bakım verici rolünün ardına gizlenmekte olup bildirilenlerden çok daha yüksek oranlarda olduğu tahmin edilmektedir (Ferguson ve Meehan 2005).-

Tüm cinsel suçların \%5’inin kadınlar tarafından işlendiği belirtilse de (Cortoni ve ark. 2010) bu oranın gerçeği yansıtmadığı düşünülmektedir (Levenson ve ark. 2015). Bourke ve arkadaşlarının (2014) çalı̧̧masında çocukluk ve ergenlik döneminde bir kadın tarafından istismara uğradığını belirtenlerin oranı \%6 olarak bulunmuştur. Peter (2009) tarafindan yapılan çalı̧̧mada ise kadınların çocuk cinsel istismarcıların \%10,7'sini oluşturduğu tespit edilmiştir. Resmi raporlar ve kişisel beyanlar arasında çok ciddi farkl1lıklar bulunmaktadır (Denov 2003). Denov (2003) resmi raporlarda \%10'un altında olan kadın cinsel istismarcı oranının, resmi sayılara yansımayan kişisel beyanlarda çok daha fazla olabildiğini dile getirmektedir. Denov'un (2003) üniversite öğrencileri ile yapılan 2 çalışmanın sentezinden elde ettiği bulgulara göre, 582 erkek ve 586 kadın katılımcıların 38’i cinsel istismara maruz 
kaldıklarını ifade etmişlerdir. Otuz sekiz katılımcının 22'si istismarcının cinsiyetini kadın, 16'sı erkek olarak belirtmiştir. Cinsel istismarın yaygınlığını tahmin etmeye çalışan en kapsamlı çalışma Finkelhor ve ark. (1990) tarafindan yürütülmüştür. Rastgele seçilmiş 2626 kadın ve erkekle telefonda görüştükleri çalışmada, erkeklerin \%16 'sı ve kadınların \%27'si cinsel istismar öyküsü bildirmiştir. Olguların çoğunda, istismarcı erkektir; ancak, istismara maruz kalan erkeklerin \%17'si bir kadın tarafından istismar edildiğini bildirirken, kadınlarda bu oran sadece \%1'dir (Gannon ve Rose 2008).

2007 yılında Birleşik Krallık Yardım Derneği Childline’a (NSPCC) yapılan çağrıların incelenmesinde, cinsel istismara uğradığını bildirenlerin \%82'si istismarcılarının cinsiyetini belirtmiştir. İstismarcılarının cinsiyetini kadın olarak belirtenlerin \%5'inin kız çocuğu ve \%44'ünün erkek çocuğu olduğu belirlenmiştir (Gannon ve Rose 2008). Gerke ve ark.'nın (2019) 2516 katılımcı ile gerçekleştirdikleri ve katılımcıların cinsel istismara yönelik deneyimlerini sorguladıkları çalışmada, cinsel istismarcıların oranı tüm katılımcılar içerisinde $\% 10,5$, bunların içerisinde de kadın cinsel istismarcıların oranı $\% 9,9$ bulunmuştur. Kadın istismarcıların mağdurlarının sıklıkla erkek olduğu ve istismarcıların dörtte birinin de çocuğun anne figürü olduğu tespit edilmiştir.

$\mathrm{Bu}$ oranlar çalışmaların hangi gruplarla yapıldığına (Tardif ve ark. 2005), çalışmanın metodolojisine (Bourke ve ark. 2014), katılımcı sayısına ve cinsel istismarın tanımına (Denov 2003) göre değişmektedir. Anne-çocuk ensest olguların yaygınlığı klinik çalışmalarda daha çok ortaya çıkmaktadır. Özellikle penetrasyon ve zorlamanın olmadığı cinsel istismar olguları klinik literatürde daha fazla yer almaktadır (Lawson 1993). Annenin bakım veren özelliği nedeniyle cinsel içerikli fiziksel temas nerdeyse hiçbir zaman cinsel istismar olarak bildirilmemektedir (Kelly ve ark. 2002).

Petrovich ve Templar (1984) çalışmalarında, tecavüzden hüküm giymiş erkeklerin önemli bir kısmının birden fazla ve sıklıkla birden çok kadın tarafından cinsel tacize uğradığını bildirmiştir. Gölge'nin (2005) çalışmasında da benzer bir sonuç bulunmuştur; yetişkine yönelik cinsel saldırıda bulunan hükümlülerin ve çocuk cinsel istismarcıların dörtte biri ilk cinsel ilişkilerini 10-15 yaş arasında gerçekleştirdiklerini ve bunların yaklaşık yarısı yetişkin bir kadınla (çoğunluğu "hayat kadını") ilk cinsel ilişkiye girdiklerini ifade etmişlerdir ancak bunu cinsel istismar olarak değerlendirmemişlerdir. Erkek çocuğunun yetişkin bir kadınla özellikle "hayat kadını” ile girdiği "cinsel ilişkiyi” istismar olarak değil de bir tecrübe olarak değerlendirmesi gerek kadın ve erkek cinselliğine ilişkin mitlerden gerekse ataerkil yapının oluşturduğu toplumsal kodlardan kaynaklanmaktadır. Kadınların cinsel anlamda pasif oldukları, cinsel olarak uyarılmadıkları için erkeklere cinsel saldırıda bulunamayacaklarına (Walfield 2018) inanılmaktadır. Kadın tarafından cinsel istismara maruz kalmı̧̧ erkek mağdurlar nadiren mağdur olarak anılmakta ve daha çok gönüllü katılımcı sayılmaktadır. Medyada dahi kadın istismarcılardan bahsedilirken tehlike ve zarardan nadiren bahsedilmektedir (Frei 2008). Toplumda, özellikle de ataerkil bir toplumda, 18 yaşından küçük bir erkek çocuk ile kendisinden büyük bir kadın arasındaki cinsel ilişki başarı olarak alg1lanmaya devam etmektedir (Helen 2009). 


\section{Kadın cinsel istismarcıların özellikleri}

Son yıllarda elde edilen bulgular erkek ve kadın cinsel istismarcılar arasında bazı benzerlikler olmasına rağmen, üzerinde daha fazla çalışılmasını gerektiren belirgin farklılıklar olduğuna işaret etmiştir (Gannon ve Rose 2008, Gannon ve Cortoni 2010, Bourke ve ark. 2014). William ve Briere'in (2015) kadın ve erkek cinsel saldırganları karşılaştırdığı çalışmada, 1991 ve 2011 yılları arasında polise intikal eden 802.150 olgu incelenmiş ve sonuçlara göre, kadın cinsel saldırganların erkeklere göre daha erken yaşta bu suçu işlediği ve kadınlar kendi çocuklarını daha fazla tercih ederken, erkeklerin üvey çocuklarını tercih ettiği saptanmıştır. Denov (2004a) tarafından yapılan nitel çalışmada, bir kadın tarafından istismara maruz kaldığını belirten yetişkin mağdurların travmatik deneyimleri ve istismarın uzun dönem etkileri araştırılmıştır. Bu çalışmada cinsel istismara maruz kalan 14 yetişkin mağdurla (7 erkek, 7 kadın) yapılan derinlemesine görüşmelerde, mağdurların \%64'ü akraba tarafindan (\%67 anne, \%22 büyükanne ve anne bir arada, \%11 anne ve kız kardeş bir arada), \%29'u yabancı tarafindan, \%7'si ise abla ve bir yabancı tarafından cinsel olarak istismar edildiğini belirtmiştir. Başka bir çalışmada ise kadınların 1/3'ünün kendi çocuğuna, \%46’sının tanıdık birine, \%12'sinin akrabasına, \%9'unun ise yabancı birine cinsel istismarda bulunduğu görülmüştür (Wijkman ve ark. 2010).

Kadınlar, erkeklere kıyasla, 12 yaş altındaki çocukları daha çok mağdur olarak seçmekte ve her iki cinsiyetten çocukları da istismar edebilmektedir (Freeman ve Sandler 2008). Mağdurların çoğu, istismarcının anne/üvey anne veya çocuk bakıcısı olarak bakımının önemli bir kısmından sorumlu olduğu okul öncesi ve okul çağındaki çocuklardır (Denov 2004a). Vandiver ve Krecher (2004) tarafından yapılan çalışmada genç kadın cinsel istismarcıların (18-25 yaş) genelde 12-17 yaşlarındaki mağdurları, daha yaşlı olanların (3378 ) ise 6 yaşından küçük çocukları istismar ettikleri bulunmuştur.

Kadın istismarcılar mağdurlarına nadiren cinsel anlamda şiddet uygulamakla birlikte, özellikle de istismarcının mağdurun annesi/üvey annesi olması halinde sıklıkla fiziksel olarak kötü muamelede bulunmaktadır (Denov 2004a). Göğüslerin öptürülmesi, karş1lıklı mastürbasyon yapma (Elliot 1994), cinsel içerikli okşama, oral seks şeklindeki aktiviteler sıklıkla görülmektedir (Elliot 1994, Denov 2004a). Kadınlar da erkek cinsel istismarcılar gibi nitelikli türdeki cinsel istismarı gerçekleştirebilmektedir (Peter 2009).

Literatürde erkeklere kıyasla kadın istismarcıların bir suç ortağıyla birlikte hareket etme olasılığının daha yüksek bulunduğu ifade edilmektedir (Mathews 1993, Grayston ve De Luca 1999, Wijkman ve ark. 2010). Ancak, Hetherton ve Beardsall (1998) ile Denov (2004a) bu görüşün kanun güçlerinde, "kadınların cinsel suç işlemeye zorlandığı" yönünde bir önyarg1 oluşturduğunu belirtmektedir. Bu bağlamda, Atkinson’ın (1995) Kanada adli kayıtlarına dayandırdığı çalışmasında, suç ortağı varlığı sanıldığı kadar yüksek oranlarda çıkmamıştır. Kadınların çoğunlukla tek başına hareket ettiği Nathan ve Ward'ın (2002) çalışmasında da gösterilmiştir. 
Çocukları tek başına istismar eden kadınların, bir erkek suç ortağı bulunan kadınlara kıyasla, 10 yaşından önce ciddi cinsel istismara maruz kaldığı belirtilmiştir (Faller 1987). Bu kadınların geçmişlerinde fiziksel, cinsel ve duygusal istismar oldukça yaygındır. Kadın cinsel istismarcıların erkek cinsel istismarcılara oranla çocuklukta daha fazla cinsel istismar ve duygusal ihmale maruz kaldığı düşünülmektedir (Miccio-Fonseca 2000, Levenson ve ark. 2015). Bu kadınların kendi anneleriyle olan ilişkileri sorunlu olup neredeyse tüm ilişkilerinde fiziksel ve psikolojik istismara rastlamak mümkündür (Lawson 2008, DeCou ve ark. 2015). Belki de bunun bir sonucu olarak, bazı çalışmalarda bu kadınların ciddi özsayg1 eksiklikleri olduğu, aile içi şiddete maruz kaldıkları ve başka tür aile sorunları yaşadıkları saptanmıştır (Hendriks ve Bijleveld 2006, Tewksbury 2004). Kadın istismarcıların büyük bir kısmı çocukluk döneminde, sıklıkla bir aile bireyi tarafindan, cinsel istismara maruz kalmıştır (Colson ve ark. 2013).

Colson ve arkadaşlarının (2013) yakın zamanlı 61 çalışmayı kapsayan geniş bir örneklem üzerinde gerçekleştirdiği meta analizde, olguların çoğunda, kadın istismarcıların imkanların kısıtlı olduğu ve kontrolün bulunmadığı evlerde büyüdüğü, ebeveynlerinin ise çok az şefkat/ sevgi gösterdiğive/veya terk edilme sorunları yaşadığı ve kişisel geçmişlerinde sevgi eksikliğive istikrarsızlık olduğu saptanmıştır. Bu durum Roe-Sepowitz ve Krysik'in (2008) çalışmasında da açık şekilde gösterilmiştir. Söz konusu çalışmada kadınların önemli çoğunluğunda, bakım veya ilgi eksikliği ve son derece dengesiz ev ortamından kaynaklanması muhtemelen - erkek cinsel suçlulardan çok daha fazla - duygusal dengesizlik saptanmıştır. Çoğu zaman, kadın cinsel suçlular ensestin yaygın olduğu; fiziksel, cinsel ve psikolojik şiddetin hüküm sürdüğü ve sıklıkla tüm bunların nesilden nesile aktarıldığı ailelerden gelmektedir (Colson ve ark. 2013).

Alanyazına bakıldığında çoğu yayında kadın istismarcılarda psikiyatrik bozuklukların öneminin vurgulandığı görülmektedir. Bazı çalışmalar, kadın cinsel istismarcılarının büyük bölümünün psikotik olmadığını fakat depresyon ve diğer kişilik bozuklukları sergilediğini göstermektedir (Green ve Kaplan 1994, Grayson ve De Luca 1999). Tutuklu kadın suçlularla yaptıkları çalışmada, Green ve Kaplan (1994) çoğu kadının geçmişinde travma sonrası stres bozukluğu ve majör depresyon öyküsü olduğunu, ayrıca dürtü kontrol sorunları dahil bir veya daha fazla kişilik bozukluğu (örn. sınır kişilik veya antisosyal kişilik bozukluğu) olduğunu tespit etmiştir. Mathews ve arkadaşları da (1989) cinsel istismarcı kadınlarda pasiflik, erkeğe bağımlılık, düşük özsaygı, kötü sosyal beceriler, reddedilme korkusu, güvensizlik ve utanç duyguları, intihar düşüncesi, öfke ve anti sosyal davranış gibi çeşitli psikolojik sorunlar saptamıştır. Çocukluk dönemi istismarı ve geçmişteki çeşitli travmatik yaşantıların yoğunluğu, kadın cinsel istismarcılarda ruh sağlığına ilişkin çeşitli bozukluklarla ilişkili olabilmektedir (DeCou ve ark. 2015).

Birçok çalışmada kadın istismarcılarda psikiyatrik bozukluk ve depresyon eğilimi bulunduğu sonucuna varılmış olmasına rağmen, Hislop’un (2001) görüşü zihinsel sorunları olmayan kadınların yakalanmaktan daha kolay kaçabildiğidir. Peter (2006), sağlık mesleği mensuplarının kadın cinsel istismarcılarda psikopatolojiler olduğu sonucuna varmalarının, psikiyatrik bozukluğu bulunmayan bir kadının cinsel suç işleyemeyeceği kalıp yargısının 
pekişmesine neden olabileceğini ileri sürmektedir. Vandiver ve Kercher (2004) ise klinik grupla çalışıldığından dolayı akıl hastalığı ve cinsel saldırılar arasındaki bağlantının abartıldığını düşünmektedir.

Kadınların uzun süreli cinsel uyarılma yaşamadıkları için pedofil olamayacakları öne sürülmüştür (Chow ve Choy 2002, Hall ve Hall 2007). Hastings'e (2000) göre de cinsel uyarılma bileşeni kadın istismarcılarda geçerli değildir çünkü erkeklere nazaran kadınlar mağdurlarını tahrik olmadan cinsel olarak istismar etmektedir. Hatta Rosencrans (1997) kendi kızına cinsel istismarda bulunan kadınların istismar etme nedeninin kendi bedenlerine veya kadınlıklarına duydukları nefretin yansıması olduğunu veya kızlarını kendi bedenlerinin bir uzantısı olarak gördüklerini ileri sürmektedir. Oysa bazı çalı̧̧malarda kadın cinsel istismarcılar haz alma amaçlı (DeCou ve ark. 2015) ve cinsel uyarılma nedeniyle (Nathan ve Ward 2002) istismarda bulunduklarını belirtmişlerdir.

\section{Kadın cinsel istismarının mağdur üzerine etkileri}

Alanyazındaki kimi çalı̧̧malarda kadın ve erkek cinsel istismarının mağdur üzerindeki etkilerinin farklılaşıp farklılaşmadığı incelenmiştir. Kadın cinsel istismarcı tarafından istismara maruz kalan erkeklerde, istismarcısı erkek olanlara kıyasla partnerine şiddet, ergenlikte takıntılı mastürbasyon ve yetişkinlikte cinsel saldırıda bulunma ve kadınlarla sorunlu ilişkiler içinde olma olasılıklarının daha yüksek olduğu ifade edilmiştir (Duncan ve Williams 1998).

Dube ve arkadaşları (2005) tarafından yaklaşık 17.000 katılımcıyla yapılan bir çalışmada ise kadın ya da erkek istismarcı mağdurlarının istismar sonrası benzer problemleri dile getirdiği ifade edilmektedir. Ancak erkek mağdurlarda kontrol grubuna kıyasla madde kullanımı erkek istismarcı olgularında 1,4 kat, kadın istismarcı olgularında ise 1,9 kat, güncel aile içi sorunlar erkek istismarcı olgularında 1,5 kat, kadın istismarcı olgularında ise 1,8 kat daha fazla görülmektedir. Erkek mağdurlarda intihar girişiminin ise kadın istismarcı mağdurlarında kontrol grubuna oranla 1,3 kat, erkek istismarcı mağdurlarında 2,6 kat daha fazla olduğu tespit edilmiştir. Genel anlamda toplumun bakışında erkeğin kadın istismarından keyif alması gerektiği (Walfield 2018) ancak erkek istismarının erkeklik ve maskülenliğe dair onurunu kırıcı bir deneyim olarak değerlendirilmesi ve mağdurların destek görmemesi (Kia-Keating ve ark. 2005) kadın istismarcı mağdurlarının intihar girişim oranlarının erkek istismarcı mağdurlara kıyasla daha düşük olmasının nedenlerinden biri olabilir. Çocuk koruma merkezine getirilen kadın istismarcı mağduru çocuklarla yapılan bir diğer çalışmada yakın dönemli olarak kaygı bozuklukları, takıntılı cinsel davranışlar ve mastürbasyon, depresyon ve saldırganlık rapor edilmiştir (Curti ve ark. 2019).

Klinik popülasyondaki anne cinsel istismarı mağdurlarının diğer kadınlar tarafından istismar edilen mağdurlara kıyasla daha fazla travma sonrası stres bozukluğu, dissosiyatif problemler, cinsel bozukluklar ve sosyal problemler yaşadıkları ifade edilmektedir (Kelly ve ark. 2002). Anneleri tarafindan istismar edilen mağdurlarda kötü bir şey yaptıkları için bu istismarı hak ettiklerine dair güçlü inanışlarla birlikte kendini suçlama eğiliminin de fazla olduğu ifade edilmektedir (Tsopelas ve ark. 2012). Anne cinsel istismarı mağdurlarının 
Rorschach testlerinde de kontrol grubuna kıyasla gerçeklik algısının daha fazla bozulduğu, daha fazla depresif semptomlar gösterdikleri, kendilerini insanlardan daha fazla izole ettikleri gözlenmiştir (Wald ve ark. 1990). Saradjian (1997) anne cinsel istismarı mağdurlarında travmatik cinsellik, anneden ayrışmakta güçlük, kendine zarar verme davranışları, başkalarına yönelik saldırganlık, ihanete uğrama hissi ve dissosiyatif belirtiler tespit etmiştir.

Çocuk için anne istismarı baba istismarından daha yaralayıcı olabilmekte, çocuğun temel bakıcı figürüne olan güvenini sarsmaktadır (Kelly ve ark. 2002, Tsopelas ve ark. 2012). Kelly ve arkadaşları (2002) tarafından kadın ve erkek istismarına maruz kalan ve kliniğe yönlendirilen 67 erkek mağdurla yapılan çalışmada anneleri tarafından istismar edilen 11 katılımcı ile babaları tarafindan istismar edilen 12 katılımcının istismar kaynaklı ruhsal semptomları karşılaştırılmı̧̧tır. Anneleri tarafından istismar edilen erkekler babaları tarafindan istismar edilen erkeklere kıyasla daha fazla cinsel sorunlar, dissosiyasyon, saldırganlık, kişilerarası sorunlar, damgalanma, kendine zarar verme belirtmişlerdir. Katılımcılar annenin istismarının en güvenilir yetişkin figüründen gelmesinin ihanete uğrama hissini daha da kuvvetlendirdiğini ifade etmektedirler. Nitekim, Denov'un (2004a) nitel çalışmasına dair anlatılarda da hem anne hem babası tarafından istismar edilen kadın mağdur, annenin istismarını daha travmatik ve saldırgan olarak nitelemektedir. Baba ensestinde kız çocuk, istismarcıyla özdeşleşme, utanç, kirlenmişlik duygularını yaşarken (Haliburn 2017), anne ensestinde kadınlığa ve anneliğe dair duygu karmaşası yaşanmaktadır (Reckling 2004).

Annenin cinsel istismarının kadın ve erkek mağdurlar için farklı sorunlara da yol açabilmesi olasıdır. Anne/üvey anneleri tarafindan cinsel istismara uğrayan erkeklerde özellikle duygusal baş etme mekanizmalarının daha fazla görüldüğü ancak bu mekanizmaların yakınlık kurma ve terk edilme korkusuyla ilişkili olduğu ifade edilmekte, bu korkuların borderline kişilik bozuklukları için de risk faktörü oluşturabileceği öne sürülmektedir (Gil 2014). Anne istismarı mağduru erkeklerle yapılan derinlemesine görüşmelerde duygusal ve cinsel ilişki kurma konusunda problemler, depresyon ve madde kullanımına sıklıkla rastlanmıştır (Krug 1989).

Anne istismarının gerçekleştiği dönemlerde kız çocuklarında bedeninden özellikle de feminen özelliklerinden utanma, kendini suçlama, ergenlik döneminde evden kaçma, uzun dönemli sonuçlarında ise benlik sorunları, kişilerarası ilişkilerde sorunlar, kendi çocuklarına temastan kaçınma gibi sorunlar görülmektedir (Tsopelas ve ark. 2012). Anne istismarının mağduru olan kadınlarda bildirimlerine inanılmamasından ve yalnız bırakılmaktan dolayı ikincil travmatizasyon, kadınlara güvensizlik, umutsuzluk, profesyonel yardım arama ihtiyacı, sorunlarla baş edememe (Peter 2008), ihanete uğramışlık hissi, düşük özgüven, kendini suçlama, benlik karmaşası (Ogilvie ve Daniluk 1995), anne olma korkusu (Ogilvie ve Daniluk 1995, Reckling 2004), anne olmuş mağdurlarda ise çocuklarına yönelik cinsel dürtüleri kontrol altına alma çabaları (Reckling 2004) ifade edilmektedir.

\section{Kadın cinsel istismarcıların tedavisi}

Cinsel suçlular için dünya genelinde çeşitli tedavi programları bulunmakla beraber, söz konusu programlar erkek faillere yönelik geliştirilmiş olup doğrudan kadın cinsel 
istismarcıları hedef alan standart bir tedavi programı veya protokolü bulunmamaktadır. Giguere ve Bumby (2007) kadın cinsel istismarcılara ilişkin mevcut müdahalelerin çoğunun erkek cinsel istismarcılarda kullanılan modellere dayandığını belirtmektedir. Mevcut çalışmalarda ise daha çok bireysel görüşme ve tedavilerin uygulandığı görülmektedir. Örneğin; İngiltere'de faaliyet gösteren bağımsız bir çocuk esirgeme kurumu olan LF (The Lucy Faitfull Foundation) 1990'lı yılların başından beri hüküm giymiş veya şüpheli durumundaki kadın çocuk cinsel istismarcıları ile birebir tedavi programları yürütmektedir. Söz konusu programda inanç sistemleri, şemalar, cinsel uyarılma, öz yönetim, ilişkiler ve insani ihtiyaçların prososyal ve pozitif yollarla karşılanması alanlarındaki sorunlara odaklanılmakta; ayrıca kadın istismarcının kendi mağduriyet geçmişi de ele alınmaktadır (Bunting 2005, Eldrigge ve ark. 2009).

Kadın istismarcıların tedavisi ile ilgili bilgilerin kısıtlılığı, mevcut az sayıdaki çalışmanın da sınırlı ve oldukça az sayıda kadın istismarcı içermesi nedeniyle, hangi tedavi yaklaşımının işe yarayacağını kestirmek güç görünmektedir. Bununla birlikte, çeşitli araştırmacıların farklı önerileri bulunmaktadır. Bu çerçevede, Nathan ve Ward (2001) klinisyenlerin istismarcının bebek, çocuk ve ergenler ile doğru biçimde etkileşime girme kapasitesini etkileyebilecek psikiyatrik bozukluklar veya akıl sağlı̆̆1 sorunlarını, istismarcının günlük hayat gereksinimleri ile başa çıkma becerisini bozan kişiler arası veya evlilik ile ilgili sorunlarını tespit etmesi gerektiğini belirtmektedir. İlaveten, Nathan ve Ward (2002) işlenen suça özgü faktörleri hedefleyen stratejilerden oluşacak kapsamlı bir tedavi programı önermektedir. Araştırmacılar bu programın düşünce ve duygular gibi suç işlemeyi tetikleyen unsurlar ile cinsel suç işleme örüntülerinin saptanması; cinsel açıdan sapkın tercihlerin kontrol edilmesi; işlenen cinsel suç ve mağduru ile ilgili bilişsel çarpıtma ve işlevsiz düşünme biçiminin hedeflenmesi; öfke, stres, kayıp ve depresyon yönetimi; sosyal beceriler ve tekrar suç işlemenin önlenmesi gibi alanları içermesi gerektiğini belirtmektedir.

Bir diğer tedavi modeli olarak da suç işlemiş bireylerin kendileri için anlamlı yaşam planları oluşturarak gelecekte yeniden suç işlememesini hedef alan ve güçlü yönler odaklı bir rehabilitasyon programı olan İyi Yaşamlar Modeli (Good Lives Model, GLM) önerilmektedir. Araştırmacılara göre, modelin dayandığı temel gerekçe tüm insanların belirli insani deneyimlere (örn. ilişkili olma, bilgi, yaratıcılık, maneviyat) ulaşma güdüsünde olduğu ve bu deneyimleri elde etmede yaşanan sorunların cinsel suç ve istismara yol açtı̆̆ şeklindedir (Ward ve Stewart 2003, Ward ve Gannon 2006). Matthews'a (1993) göre, kadın cinsel istismarcıların değerlendirilmesinde ve tedavisinde istismarcının çocukluk, ergenlik veya yetişkinlik dönemine ilişkin fiziksel, duygusal, cinsel ve psikolojik istismar öyküsünün bilinmesi de kritik önem taşımaktadır.

\section{Sonuç}

$\mathrm{Bu}$ makale kapsamında, kadın istismarcılara ilişkin literatür incelenmiştir. Bu inceleme sonucunda günümüzde kadın istismarcılara yönelik bilginin halen son derece sınırlı olduğu görülmüş̧ür. Sınırlı sayıdaki bu çalışmalarda kadın cinsel istismarcıların oranı erkelere göre oldukça düşük bulunmuştur. Fakat kadın istismarcılar, kadının bakım verici rolü 
nedeniyle istismarcı olarak etiketlenmeden çocuklara gösterebilecekleri daha geniş temas davranışlarında bulunabilmektedir. Aynı zamanda banyo yapma ve çocuk giydirme gibi annelik rollerinin bir parçası olarak üstlenilen günlük faaliyetler sırasında kötüye kullanım veya uygunsuz davranışları gizleyebilmektedir. Kadın istismarcılar, kadının annelik ve bakım verici rolünün arkasına saklanma olasılığı nedeniyle sayıca az olsa da toplum için ciddi bir sorundur. Abel ve Harlow'un (2001) Çocuklara Yönelik Cinsel Tacizi Önleme Çalışmasının sonuçları bu soruna dikkat çekmektedir. Araştırmanın örneklemi olan 16.000 kişiden yalnızca 601'i kadındır. Çocuk istismarcısı olduğunu kabul eden 4.000 kişiden ise yalnızca \%1,4'ü kadındır. Ancak istismarcı olan çocuk bakım merkezi çalışanları arasında, kadınlar $\% 40$ 'lık bir orana tekabül etmektedir. Bu nedenle önleme çalışmalarında kadın istismarcının varlığ 1 ve riskleri konusunda farkındalık yaratılmalıdır.

Birçok standart teorik çerçeveler, değerlendirmeler ve klinik tedavi prosedürleri, erkek cinsel suçlular için geliştirilmiş ve klinisyenler bu konuda çok iyi eğitilmiştir, ancak bu değerlendirmeler ve klinik prosedürler kadın istismarcılarına yönelik hiçbir zaman onaylanmamı̧̧ veya test edilmemiştir. Cinsel suçlularla ilgili yetkili klinik uygulama, geçerli bilim-pratiği modeli çerçevesinde oluşturulur, bu uygulamanın kadın istismarcılarda da oluşturulması için, mevcut ampirik veriler hakkında bilgi sahibi olunması gerekmektedir. Araştırma kanıtları (a) erkek ve kadın cinsel suçluların psikolojik işleyişini çeşitli yönleriyle karşılaştırmalı ve (b) kadın cinsel istismarına özgü etiyolojik öneme sahip unsurları ortaya çıkarmak için kadın cinsel suçluları, erkek cinsel suçlulardan bağımsız olarak incelemelidir (Gannon ve Rose 2008). Bu alanda gelecekte yapılacak araştırmaların, kadın cinsel istismarcıların rehabilitasyonuna ve klinik yöntemlere odaklanması gerekmektedir. Yapılacak ampirik çalışmalar da daha etkili klinik uygulamaları teşvik edecektir.

Ayrıca, bu çalı̧̧ma kapsamında yapılan araştırma sonucunda Türkiye'de kadın istismarcılara dair ciddi ve düzenli veri olmadığı görülmüştür. Çocuk istismarının yaygın görüldüğü ülkemizde, bu konunun önemi daha da öne çıkmaktadır. Dolayısıyla, kadın cinsel istismarcılar hakkında Türkiye'de yürütülecek çalışmalara ihtiyaç vardır.

\section{Kaynaklar}

Abel GG, Harlow N (2001) The Stop Child Molestation Book: What Ordinary People Can Do In Their Everyday Lives To Save 3 Million Children. Philadelphia, Pa, Xlibris.

Akdemir S, Gölge ZB (2019) Kadın cinsel istismarcılara yönelik tutumlar ölçeği'nin Türkçe geçerlik ve güvenirlik çalışması. In Sosyal Bilimlerde Güncel Akademik Çalışmalar, 2 (Eds T Erdoğan, S Özer): 113-127. Çetinje, Montenegro, Ivpe.

Atkinson J (1995) The Assessment of Female Sex Offenders. Kingston, Correctional Service of Canada.

Banning A (1989) Mother-son incest: confronting a prejudice. Child Abuse Negl, 13:563-570.

Becker JV, Hall SR, Stinson JD (2001) Female sexual offenders: clinical, legal and policy issues. J Forensic Psychol Pract, 1:29-50.

Boroughs DS (2004) Female sexual abusers of children. Child Youth Serv Rev, 26:481-487.

Bourke A, Doherty S, McBride 0, Morgan K, McGee H (2014) Female perpetrators of child sexual abuse: characteristics of the offender and victim. Psychol Crime Law, 20:769-780.

Broussard S, Wagner NG, Kazelskis R (1991) Undergraduates students' perceptions of child sexual abuse: the impact of victim sex, perpetrator sex, respondent sex, and victim response. J Fam Violence, 6:267-278.

Bunting L (2005) Females Who Sexually Offend Against Children: Responses of The Child Protection and Criminal Justice Systems. London, NSPCC. 
Cain CM, Anderson AL (2016) Female sex offenders: public awareness and attributions. Violence Vict, 31:1044-1063.

Center for Sex Offender Management (2007) Female Sex Offenders. Maryland, Center for Sex Offender Management.

Chow EWC, Choy AL (2002) Clinical characteristics and treatment responses to SSRl in a female pedophile. Arch Sex Behav, 31:211215.

Colson MH, Boyer L, Baumstarck K, Loundou AD (2013) Female sex offenders: a challenge to certain paradigmes. Meta-analysis. Sexologies, 22:109-117.

Cortoni F, Hanson RK, Coache M (2010) The recidivism rates of female sexual offenders are low: a meta-analysis. Sex Abuse, 22:387401.

Curti SM, Lupariello F, Coppo E, Praznik EJ, Racalbuto SS, Di Vella G (2019) Child sexual abuse perpetrated by women: case series and review of the literature. J Forensic Sci, 64:1427-1437.

DeCou CR, Cole TT, Rowland SE, Kaplan SP, Lynch SM (2015) An ecological process model of female sex offending: the role of victimization, psychological distress, and stressors. Sex Abuse, 27:302-323.

Denov MS (2003) The myth of innocence: sexual scripts and the recognition of child sexual abuse by female perpetrators. J Sex Res, 40:303-314.

Denov MS (2004a) The long-term effects of child sexual abuse by female perpetrators: a qualitative study of male and female victims. J Interpers Violence, 19:1137-1156.

Denov MS (2004b) Perspectives on Female Sex Offending: A Culture of Denial. Burlington, Ashgate.

Dube SR, Anda RF, Whitfield CL, Brown DW, Felitti VJ, Dong M (2005) Long-term consequences of childhood sexual abuse by gender of victim. Am J Prev Med, 28:430-438.

Duncan LE, Williams LM (1998) Gender role socialization and male-on-male vs. female-on-male child sexual abuse. Sex Roles, 39:765-785.

Eldridge HJ, Elliott IA, Ashfield S (2009) Assessment of women who sexually abuse children. In Sexual Abuse Assessments: Using and Developing Frameworks for Practice (Ed MC Calder):213-227. Lyme Regis, UK, Russell House Publishing.

Elliott M (1994) Female sexual abuse of children: 'the ultimate taboo'. J R Soc Med, 87:691-694.

Faller KC (1987) Women who sexually abuse children. Violence Vict, 2:263-276.

Ferguson (J, Meehan DC (2005) An analysis of females convicted of sex crimes in the state of Florida. J Child Sex Abus, 14:75-89.

Finkelhor D, Russell D (1984) Women as perpetrators. In Child Sexual Abuse: New Theory and Research (Eds D Finklehor):171-187. New York, Free Press.

Finkelhor D, Williams L, Burns N (1988) Nursery Crimes: Sexual Abuse in Day Care. Newburry Park, CA, Sage.

Ford H (2006) Women Who Sexually Abuse Children. Sussex, Wiley.

Freeman JN, Sandler CJ (2008) Female and male sex offenders: a comparison of recidivism patterns and risk factors. J Interpers Violence, 23:1394.

Frei A (2008) Media consideration of sex offenders: how community response shapes a gender perspective. Int I Offender Ther Comp Criminol, 52:495-498.

Gannon TA, Cortoni F (2010) Female Sexual Offenders: Theory, Assessment, and Practice. Chichester, UK, Wiley-Blackwell.

Gannon TA, Rose MR (2008) Female child sexual offenders: towards integrating theory and practice. Aggress Violent Behav, 13:442461.

Gerke J, Rassenhofer M, Witt A, Sachser C, Fegert JM (2019) Female-perpetrated child sexual abuse: prevalence rates in Germany. J Child Sex Abus, 29:263- 277.

Giguere R Bumby K (2007) Female Sex Offenders. Silver Spring, Maryland, Center For Sex Offender Management.

Gil S (2014) Male victims of childhood sexual abuse by a male or female perpetrator. J Trauma Stress Disord Treat, 3:1-6.

Gölge ZB (2005) Cinsel saldırıda etkili faktörler ve suçlu profile (Doktora tezi). İstanbul, İstanbul Üniversitesi.

Grayston AD, De Luca RV (1999) Female perpetrators of child sexual abuse: a review of the clinical and empirical literature. Aggress Violent Behav, 4:93-106.

Green AH, Kaplan MS (1994) Psychiatric impairment and childhood victimisation experiences in female child molesters. J Am Acad Child Adolesc Psychiatry, 33:954-961.

Gren A (1996) Child sexual abuse and incest. In Child and Adolescent Psychiatry: A Comprehensive Textbook, 2nd ed (Ed M Lewis):1041-1048. Baltimore, MA, Williams \&Wilkins. 
Haliburn J (2017) Mother-child incest, psychosis, and the dynamics of relatedness, J Trauma Dissociation, 18:409-426

Hall RCW, Hall RCW (2007) A profile of pedophilia: definition, characteristics of offenders, recidivism, treatment outcomes, and forensic issues. Mayo Clin Proc,82:457- 471.

Hastings AS (2000) From Generation to Generation: Understanding Sexual Attraction to Children. Stevens Point, WI, National Wellness Institute.

Helen G (2009) "Mummy wouldn't do that" the perception and construction of the female child sex abuser. In Grotesque Femininities: Evil, Women and the Feminine (Ed M. Barrett):61-78. 0xford, UK, Inter-Disciplinary Press.

Hendriks J, Bijleveld CCH (2006) Female adolescent sex offenders: an exploratory study. J Sex Aggress, 12:31-41.

Hetherton J, Beardsall $L$ (1998) Decisions and attitudes concerning child sexual abuse: does the gender of the perpetrator make a difference to child protection professionals? Child Abuse Negl, 22:1265-1283.

Herzog S, Oreg $S$ (2008) Chivalry and the moderating effect of ambivalent sexism: individual differences in crime seriousness judgments. Law Soc Rev, 42:45-74.

Hislop J (2001) Female Sex Offenders: What Therapists, Law Enforcement and Child Protective Services Need to Know. Ravensdale, WA, Issues Press.

Johansson-Love J, Fremouw W (2006) A critique of the female sexual perpetrator research. Aggress Violent Behav, 11:12-26.

Kaufman KL, Wallace AM, Johnson CF, Reeder ML (1995) Comparing female and male perpetrators' modus operandi: victims' reports of sexual abuse. J Interpers Violence, 10:322-333.

Kelly RJ, Wood JJ, Gonzalez LS, MacDonald V, Waterman J (2002) Effects of mother-son incest and positive perceptions of sexual abuse experiences on the psychosocial adjustment of clinic-referred men. Child Abuse Negl, 26:425-441.

Kia-Keating M, Grossman FK, Sorsoli L, Epstein M (2005) containing and resisting masculinity: narratives of renegotiation among resilient male survivors of childhood sexual abuse. Psychol Men Masc, 6:169-185.

Krug RS (1989) Adult male report of childhood sexual abuse by mothers: case descriptions, motivations and long-term consequences. Child Abuse Negl, 13:111-119.

Lawson C (1993) Mother-son sexual abuse: Rare or underreported? a critique of the reseach. Child Abuse Negl, 17:261-269.

Lawson L (2008) Female sex offenders' relationship experiences. Violence Vict, 23:331-343.

Levenson JS, Willis GM, Prescott DS (2015) Adverse childhood experiences in the lives of female sex offenders. Sex Abuse, 27:258-283.

Matthews JK (1993) Working with female sexual abusers. In Female Sexual Abuse of Children (Ed M Elliot):57-73. New York, NY, Guilford Press.

Mathews R, Matthews JK, Speltz K (1989) Female Sexual Offenders: An Exploratory Study. Orwell, VT, Safer Society Press.

Mendel MP (1995) The Male Survivor: The Impact of Sexual Abuse. London, Sage.

Miccio-Fonseca LC (2000) Adult and adolescent female sex offenders: experiences compared to other female and male sex offenders. J Psychol Human Sex, 11:75-88.

Nathan P, Ward T (2001) Females who sexually abuse children: assessment and treatment issues. Psychiatr Psychol Law, 8:44-45.

Nathan P, Ward T (2002) Female sex offenders: clinical and Demographic Features. gJ Sex Aggress, 8:5-21.

Ogilvie B, Daniluk J (1995) Common themes in the experiences of mother-daughter incest survivors: implications for counseling. J Couns Dev, 73:598-602.

Peter T (2006) Mad, bad, or victim? making sense of mother-daughter sexual abuse. Fem Criminol, 1:283-302.

Peter T (2008) Speaking about the unspeakable exploring the impact of mother-daughter sexual abuse. Violence Against Women, 14:1033-1053.

Peter T (2009) Exploring taboos comparing male and female perpetrated child sexual abuse. J Interpers Violence, 24:1111-1128.

Petrovich M, Templer DI (1984) Heterosexual molestation of children who later became rapists. Psychol Rep, 54:810.

Prahlada Rao N, Chand PK, Murthy P (2007) A case of late onset pedophilia and response to sertraline. Prim Care Companion J Clin Psychiatry, 9:235-236.

Reckling AE (2004) Mother-Daughter Incest. J Trauma Pract, 3:49-71.

Roe-Sepowitz D, Krysik J (2008) Examining the sexual offenses of female juveniles: the relevance of childhood maltreatment. Am J Orthopsychiatry, 78:405-12.

Rosencrans B (1997) The Last Secret: Daughters Sexually Abused by Mothers. Brandon, VT, The Safer Society Press. 
Saradjian J (1997) Factors that specifically exacerbate the trauma of victims of childhood sexual abuse by maternal perpetrators. J Sex Aggress, 3:3-14.

Tardif M, Auclair N, Jacob M, Carpentier, J (2005) Sexual abuse perpetrated by adult and juvenile females: an ultimate attempt to resolve a conflict associated with maternal identity. Child Abuse Negl, 29:153-167.

Tewksbury R (2004) Experiences and attitudes of registered female sex offenders. Fed Probat, 68:30-33.

Tsopelas C, Tsetsou S, Ntounas P, Douzenis A (2012) Female perpetrators of sexual abuse of minors: what are the consequences for the victims Int J Law Psychiatry, 35:305-310.

Vandiver DM (2006) Female sex offenders: a comparison of solo offenders and co-offenders. Violence Vict, 21:339-354.

Vandiver DM, Kercher $G$ (2004) Offender and victim characteristics of registered female sexual offenders in Texas: a proposed typology of female sexual offenders. Sex Abuse, 16: 121-137.

Wald BK, Archer RP, Winstead BA (1990) Rorschach characteristics of mothers of incest victims. J Pers Assess, 55:417-425.

Walfield, SM (2018) "Men cannot be raped": Correlates of male rape myth acceptance. J Interpers Violence, 1-27.

Ward T, Gannon TA (2006) Rehabilitation, etiology, and self-regulation: The good lives model of rehabilitation for sexual offenders. Aggress Violent Behav, 11:77-94.

Ward T, Stewart CA (2003) The treatment of sex offenders: risk management and good lives. Prof Psychol Res Pr, 34:353-360.

Wijkman M, Bijleveld C, Hendricks J (2010) Women don't do such things! characteristics of female sex offenders and offender types. Sex Abuse, 22:135-156.

Williams KS, Briere DM (2015) An Incident-based comparison of female and male sexual offenders. Sex Abuse, 27:235-257.

Yoder J (2003) Women and Gender: Transforming Psychology. Hoboken, NJ, Prentice Hall.

Yazarların Katkıları: Yazarlar çalışmaya önemli bir bilimsel katkı sağladıklarını ve makalenin hazırlanmasında veya gözden geçirilmesinde yardımcı olduklarını kabul etmişlerdir.

Danışman Değerlendirmesi: Dış bağımsız.

Çıkar Çatışması: Yazarlar çıkar çatışması bildirmemiştir.

Finansal Destek: Yazarlar bu çalışma için finansal destek almadı̆ğını beyan etmiştir.

Authors Contributions: The authors attest that they made an important scientific contribution to the study and have assisted with the drafting or revising of the manuscript.

Peer-review: Externally peer-reviewed.

Conflict of Interest: No conflict of interest was declared by the authors.

Financial Disclosure: The authors declared that this study has received no financial support. 